Article

\title{
Successful Eradication of the Asian Longhorn Beetle, Anoplophora glabripennis, from North-Eastern Italy: Protocol, Techniques and Results
}

\author{
Matteo Marchioro *(D) and Massimo Faccoli (D) \\ Department of Agronomy, Food, Natural Resources, Animals and the Environment, University of Padua, \\ 35122 Padova, Italy; massimo.faccoli@unipd.it \\ * Correspondence: matteo.marchioro@phd.unipd.it; Tel.: +39-049-8272811
}

check for updates

Citation: Marchioro, M.; Faccoli, M. Successful Eradication of the Asian Longhorn Beetle, Anoplophora glabripennis, from North-Eastern Italy: Protocol, Techniques and Results. Insects 2021, 12, 877. https: / / doi.org/ $10.3390 /$ insects 12100877

Academic Editor: Jian J. Duan

Received: 3 September 2021

Accepted: 24 September 2021

Published: 28 September 2021

Publisher's Note: MDPI stays neutral with regard to jurisdictional claims in published maps and institutional affiliations.

Copyright: (c) 2021 by the authors. Licensee MDPI, Basel, Switzerland. This article is an open access article distributed under the terms and conditions of the Creative Commons Attribution (CC BY) license (https:// creativecommons.org/licenses/by/ $4.0 /)$.
Simple Summary: Anoplophora glabripennis (Coleoptera: Cerambycidae) is an extremely polyphagus Asian wood-boring beetle accidentally introduced into North America and Europe. In 2009, an infestation was found in the municipality of Cornuda (Veneto Region, Italy). In order to eradicate the pest, several actions were immediately undertaken in the delimitated infested and buffer zones: tree visual inspections twice a year, felling and chipping of infested and suspected trees, trapping protocols, mitigation plans based on substitution of felled trees with new plants, and citizen alerts. The program lasted 11 years, after which the species was declared eradicated from the region. During the eradication program more than 36,000 trees were surveyed and more than 2000 trees were felled. Trees most affected by the pest were birches, elms, maples, and willows. This paper describes all the actions undertaken during the eradication program, providing a protocol that can also be used for future eradications of the species.

Abstract: The Asian Longhorn Beetle (ALB), Anoplophora glabripennis (Coleoptera: Cerambycidae), is an important and extremely polyphagous wood-boring beetle native to Asia. In the 1990s, ALB was accidentally introduced into North America and Europe. In 2009, a large ALB infestation was found in the Veneto Region (north-eastern Italy), in the municipality of Cornuda (Treviso province). Eradication actions were immediately undertaken, based on delimitation of infested and buffer zones, tree visual inspections, felling and chipping of infested trees, trapping protocols, and citizen alerts. A total of 36,361 trees, belonging to 16 genera, were surveyed twice a year over an area of 7594 hectares. In 2020, after 11 years of eradication measures, the ALB population of Cornuda was declared eradicated. Overall, 2361 trees belonging to 8 genera were felled and destroyed, of which 1157 were found to be infested by ALB. This paper describes all the actions carried out and the procedures applied in order to eradicate ALB from north-eastern Italy, providing a useful example for current and future ALB eradication programs.

Keywords: Cerambycidae; invasive pest; eradication program; ALB

\section{Introduction}

The Asian Longhorn Beetle (ALB), Anoplophora glabripennis (Motschulsky) (Coleoptera Cerambycidae), is a wood-boring beetle native to China and the Korean Peninsula [1]. Although in its native range A. glabripennis mainly infests Populus spp., Salix spp., Ulmus spp., and Acer spp. [2], A. glabripennis is an extremely polyphagous pest able to develop on woody broadleaves of 34 tree species belonging to 14 genera in 10 families [1,3]. A. glabripennis attacks both young and mature trees growing in urban and peri-urban areas [3-5]. Unlike most longhorn beetles, A. glabripennis develops in apparently healthy plants, although it can also infest stressed trees and fresh logs [6,7]. For these reasons, the introduction of A. glabripennis in new areas represents an enormous threat to urban parks and rural forests $[8,9]$. 
Accidentally introduced with infested wood packaging material associated with international trade [3], A. glabripennis was first found outside its native range in New York City (NY, USA) in $1996[10,11]$. Following this, the pest was found also in other states of the USA (Illinois, New Jersey, Massachusetts, Ohio, and South Carolina) [4,12-15], in Canada (Ontario) [16], and in Europe, where the first presence of A. glabripennis was recorded in Austria (2001) [17], followed by France (continental) (2003) [18], Germany (2004) [19], Italy (2007) [20], the Netherlands (2010) [21], Switzerland (2011) [22], the UK (2012) [23], Corse (2013) [24], Finland (2015) [25], and Montenegro (2015) [26]. After eradication measures undertaken by different states, to date, infestations of the pest still occur in France (both continental and Corse), Germany, Italy, and the USA [27].

In Italy A. glabripennis was found in the northern regions of Lombardy (2007) [20], Veneto (2009) [28], Piedmont (2018) [29], and in the central region of Marche (2013) [30]. At these latitudes the whole A. glabripennis life cycle lasts 12-18 months (Faccoli, pers. observ.). Adults emerge in summer, mainly in late June-early July [31]. After maturation feedings and mating, the female lays eggs in oviposition pits chewed out under the bark of the host tree [31]. Young larvae initially feed on phloem and, starting from the third instar, they complete their development in the wood [32]. Pupation lasts a couple of weeks, in a pupal chamber created by mature larvae in the sapwood, and the new adult emerges through a circular hole (about $10 \mathrm{~mm}$ diameter, smaller in males) [32]. In Europe, complete development of $A$. glabripennis has been recorded on many genera of woody broadleaves.

The A. glabripennis infestation occurring in north-eastern Italy (Veneto Region) was discovered in June 2009 in the municipality of Cornuda [28,33]. A maple was found to be infested in a private garden of the city center following a report of the garden owner to the local phytosanitary office of the Regional Plant Protection Organization (RPPO). The infested tree showed all the typical symptoms of A. glabripennis infestation, with large and circular emergence holes, sectorial dieback of the canopy with dead branches, and oviposition pits along the stem. Immediately after the discovery of the pest, a large-scale intensive monitoring and eradication program started. The eradication program was based on the establishment of buffer zones, visual inspections, felling and destruction of infested trees, trapping protocols, and citizen alerts, following the official guidelines issued by EPPO [34]. The A. glabripennis population of Cornuda was declared eradicated in 2020 [35], after 11 years of application of specific control measures. The aim of this paper is to present and describe all the actions and procedures successfully carried out in order to eradicate A. glabripennis from north-eastern Italy.

\section{Materials and Methods}

\subsection{Site Description}

The municipality of Cornuda $\left(45^{\circ} 830^{\prime} \mathrm{N}, 12^{\circ} 010^{\prime} \mathrm{E}\right.$; Italy), is located along the southern border of the Italian Alps, approximately $160 \mathrm{~m}$ a.s.l., in a transition from continental to Mediterranean climatic conditions, with temperate summers and winters. Annual precipitation ranges from 1100 to $1200 \mathrm{~mm}$, concentrated in the spring and autumn. Cornuda is a small village of about 6200 inhabitants located in a suburban area fallowing within a hilly landscape with patches of agricultural land. The village structure consists mainly of small, isolated houses surrounded by small private gardens often containing ornamental trees represented by woody native or exotic broadleaves. Public tree-lined parks and rows of trees along the streets are also common.

The village is closely surrounded by mixed deciduous forests and riparian habitats which develop along the Piave river. Natural forests are primarily composed of Acer pseudoplatanus L., Carpinus betulus L., Fagus sylvatica L., Fraxinus excelsior L. and Quercus robur L. on shady damp slopes, as well as Betula pendula Roth., Fraxinus ornus L., Ostrya carpinifolia Scopoli and Quercus pubescens Willd. on sunny dry slopes. 


\subsection{Tree Database}

Since the first record of the A. glabripennis in June 2009, an extensive monitoring program started, visually checking one-by-one all of the possible host trees occurring in Cornuda and in the surrounding municipalities (see next paragraphs), with search directions radially oriented from the point of first discovery of the pest. All host trees were also geo-referenced, creating a specific database reporting information about the plant (genera, age, general physiological conditions), geographic position (coordinates), and ownership data (owner name, address and phone number). Some import-export companies work in in the Cornuda territory, with frequent commercial trade with China. As the infestation may have originated from these companies, particular attention was paid to surveying their surrounding areas.

\subsection{Visual Tree Survey}

After the first survey carried out in summer 2009, with the creation of the tree database, a systemic and continuative survey of the host-plants started, choosing the most susceptible tree genera according to the literature: Acer, Aesculus, Alnus, Betula, Carpinus, Cercidiphyllum, Corylus, Fagus, Fraxinus, Ostrya, Platanus, Populus, Prunus, Salix, Tilia and Ulmus [3,4]. The aim of the survey was to discover the presence of A. glabripennis-infested plants and update the infested and buffer areas accordingly. The survey was conducted by 3 teams of operators each composed by 2 trained technicians of the Regional Plant Protection Organization that checked all the host-trees one-by-one from the ground, with the use of binoculars looking for A. glabripennis infestation symptoms. All host-trees were georeferenced and checked twice a year, in summer and late-autumn, looking for adult exit holes, larval frass emission, oviposition scars, maturation feedings on twigs, tree decline with branch dieback, and presence of adults on branches and canopies (Figure 1). On one hand, some symptoms are recognizable more easily in summer, such as the presence of recently emerged adults, fresh oviposition pits on the bark, maturation feedings performed by immature adults on twigs, and occurrence of dying branches. On the other hand, the presence of emerging holes is more visible in late autumn after the plants have lost leaves and the upper branches and canopy are easily checkable from the ground. In case of large trees or plants having trunk and branches covered with ivy, difficult to check from ground with accuracy, the inspectors of the Phytosanitary Service were supported both in summer and winter by a team of 4 tree-climbers from the Treviso Forest Service, who also checked for the potential presence of symptoms in the upper part of the canopy.

Forested areas neighboring the village of Cornuda and falling within the infested or buffer areas were surveyed once per year, along the main forest edges (i.e., external edges, forest tracks, and clear-cut edges). A strip at least $30 \mathrm{~m}$ deep inside the forest was monitored. Studies conducted in native regions of South Korea suggest that $A$. glabripennis is not a true forest species but is adapted to riparian habitats characterized by long edges [36]. Similarly, in countries where they are introduced, A. glabripennis infestations are usually limited to urban trees that are isolated, growing in small groups or rows, in small rural stands or along forest edges [3,4]. 




Figure 1. Main symptoms of A. glabripennis infestation: presence of adults (a), adult exit holes (b), oviposition scars (c), maturation feedings on twigs (d).

\subsection{Zone Delimitation}

After the checking of all host plants growing in the area, the infested and buffer zones were established (Figure 2). The "infested zone" consisted of a polygon including all the infested plants, where the vertices of the polygon were the more external infected plants. The infested zone was included in the territory of six municipalities (Cornuda, Pederobba, Crocetta del Montello, Maser, Montebelluna and Caerano di San Marco). Then, a "buffer zone" was established with a radius of $2 \mathrm{~km}$ around the infested zone, i.e., around the most external infested trees, according to European regulations [34]. Year-by-year, when new infested trees were found, the delimited zones (infested and buffer zones) were officially extended (or restricted) several times, coming to also include the bordering municipalities where satellite infestations have been discovered since 2010 . 


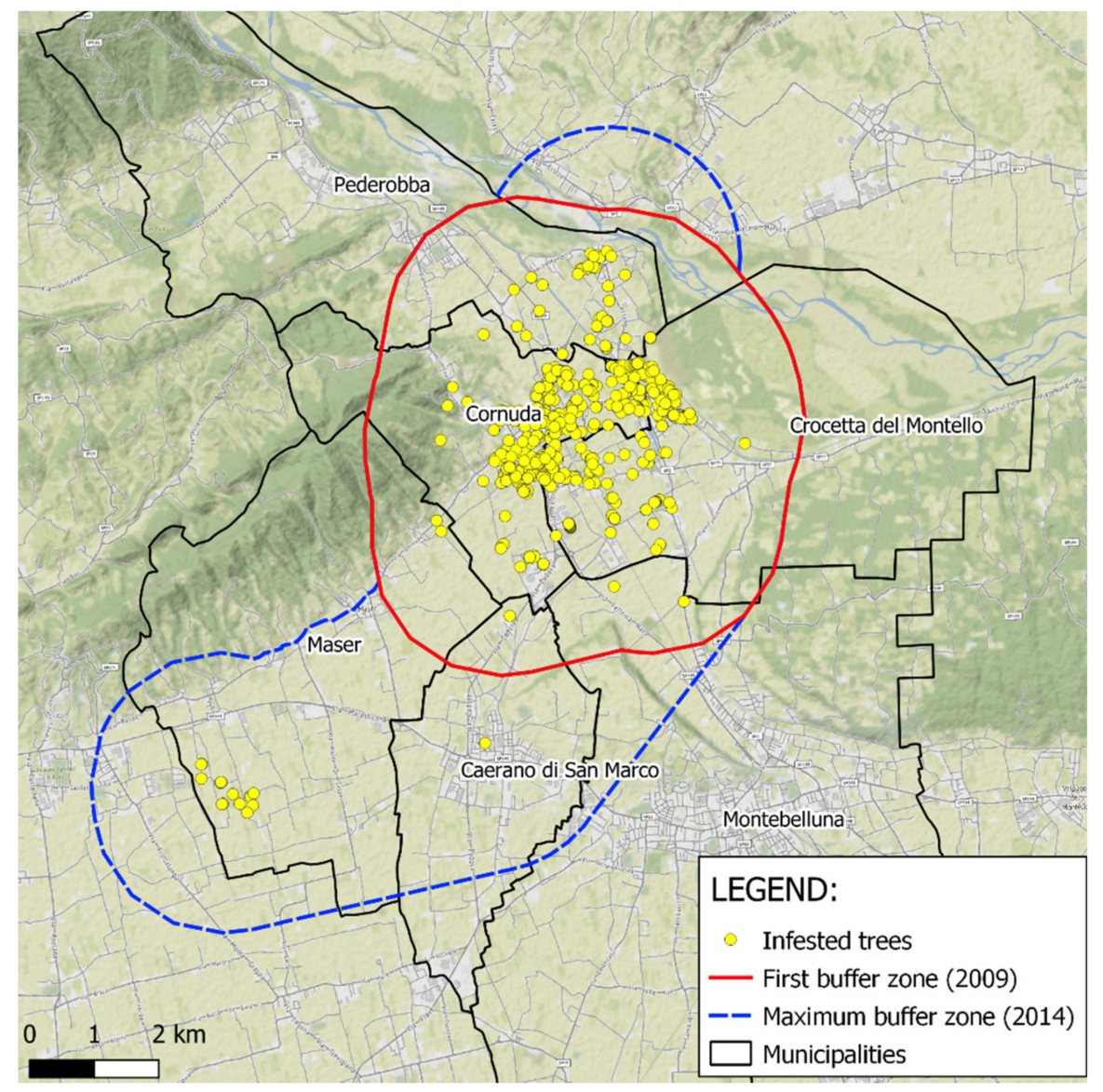

Figure 2. Map of the A. glabripennis infestation, with position of infested trees, involved municipalities border and first and maximum buffer zones extension.

\subsection{Pheromone Traps}

During the eradication program, trapping protocols were carried out in the buffer zone in order to verify the presence of $A$. glabripennis in the territory and to test the effectiveness of different trapping tools (i.e., trap models and lures). The sites for trap-setting were chosen in relation to the concentration of susceptible hosts and in suitable areas near the edge of the delimited zone.

In 2011, 14 traps of different type, size, and color were placed for one month (August) and checked weekly (Table 1). Traps were baited with a blend produced by ChemTica International (Heredia, Costa Rica). In 2012, 27 black cross-vane traps were set up and baited with either the ChemTica blend used in 2011, or a Russian experimental blend provided in six different formulations by Dr. Oleg Kulinich of the Department of Forest Quarantine, of the All-Russian Center of Plant Quarantine of Moscow. Traps were checked three times during July, the month with the highest emergence of $A$. glabripennis adults [31]. In 2013, 24 traps were placed: 6 control unbaited traps, and 6 others for each of three different blends, equally divided (ChemTica blend and two new formulations of the Russian blend). Lastly, in 2019, ten black cross-vane traps were set in the delimited zone and checked every 2 weeks from middle June to middle September, in order to support the action of visual inspections and verify if $A$. glabripennis was successfully eradicated. Traps were baited with the ChemTica blend tested in the previous year. The used trap types and lure formulations are summarized in Table 1. 
Table 1. Information about detection tools used during the eradication program. For each year information was reported about the trap model (type and color), the trap number, and the type of lure.

\begin{tabular}{|c|c|c|c|c|}
\hline Year & Trap Type & Trap Color & Trap Number & Lure \\
\hline \multirow{6}{*}{2011} & Cross-vane, long & Black & 2 & \multirow{6}{*}{ CHEMTICA } \\
\hline & Cross-vane, long & Transparent & 1 & \\
\hline & Cross-vane, short & Black & 1 & \\
\hline & Cross-vane, short & Transparent & 3 & \\
\hline & Multi-funnel, long & Black & 3 & \\
\hline & Multi-funnel, short & White & 4 & \\
\hline \multirow{7}{*}{2012} & \multirow{7}{*}{ Cross-vane, long } & \multirow{7}{*}{ Black } & 3 & CHEMTICA \\
\hline & & & 4 & RUSSIAN (I) \\
\hline & & & 4 & RUSSIAN (II) \\
\hline & & & 4 & RUSSIAN (III) \\
\hline & & & 4 & RUSSIAN (IV) \\
\hline & & & 4 & RUSSIAN (V) \\
\hline & & & 4 & RUSSIAN (VI) \\
\hline \multirow{8}{*}{2013} & \multirow{4}{*}{ Cross-vane, long } & \multirow{4}{*}{ Black } & 3 & CONTROL \\
\hline & & & 3 & CHEMTICA \\
\hline & & & 3 & RUSSIAN (VII) \\
\hline & & & 3 & RUSSIAN (VIII) \\
\hline & \multirow{4}{*}{ Multi-funnel, long } & \multirow{4}{*}{ Black } & 3 & CONTROL \\
\hline & & & 3 & CHEMTICA \\
\hline & & & 3 & RUSSIAN (VII) \\
\hline & & & 3 & RUSSIAN (VIII) \\
\hline 2019 & Cross-vane, long & Black & 10 & CHEMTICA \\
\hline
\end{tabular}

Blends legend:

CHEMTICA = 1:1 ratio of 4-(n-heptyloxy)butanal $(0.3 \mathrm{mg})$ and 4-(n-heptyloxy)butan-1-ol $(0.3 \mathrm{mg})+(-)$-linalool $(3 \mathrm{mg})+$ trans-caryophyllene (3 mg) + (Z)-3-hexen-1-ol (3 mg)

RUSSIAN $(\mathrm{I})=1: 1$ ratio of 4 -(n-heptyloxy)butanal $(5 \mu \mathrm{L})$ and 4 -(n-heptyloxy)butan-1-ol $(5 \mu \mathrm{L})$

RUSSIAN (II) = 1:1 ratio of 4-(n-heptyloxy)butanal $(50 \mu \mathrm{L})$ and 4-(n-heptyloxy)butan-1-ol $(50 \mu \mathrm{L})$

RUSSIAN (III) = 1:1 ratio of 4-(n-heptyloxy)butanal $(500 \mu \mathrm{L})$ and 4 -(n-heptyloxy)butan-1-ol $(500 \mu \mathrm{L})$

RUSSIAN $(I V)=1: 1$ ratio of 4-(n-heptyloxy)butanal $(5 \mu \mathrm{L})$ and 4 -(n-heptyloxy)butan-1-ol $(5 \mu \mathrm{L})+(\mathrm{Z})$-3-hexen-1-ol $(100 \mu \mathrm{L})$

RUSSIAN $(\mathrm{V})=1: 1$ ratio of 4-(n-heptyloxy)butanal $(50 \mu \mathrm{L})$ and 4-(n-heptyloxy)butan-1-ol $(50 \mu \mathrm{L})+(\mathrm{Z})-3$-hexen-1-ol $(1000 \mu \mathrm{L})$

RUSSIAN (VI) = 1:1 ratio of 4-(n-heptyloxy)butanal $(500 \mu \mathrm{L})$ and 4-(n-heptyloxy)butan-1-ol $(500 \mu \mathrm{L})+(\mathrm{Z})-3-\mathrm{hexen}-1-\mathrm{ol}(3000 \mu \mathrm{L})$

RUSSIAN (VII) = 1:1 ratio of 4-(n-heptyloxy)butanal $(0.3 \mathrm{mg})$ and 4-(n-heptyloxy)butan-1-ol $(0.3 \mathrm{mg})+(-)$-linalool (3 mg)

RUSSIAN $($ VIII $)=1: 1$ ratio of 4-(n-heptyloxy)butanal $(0.6 \mathrm{mg})$ and 4 -(n-heptyloxy)butan-1-ol $(0.6 \mathrm{mg})+(-)$-linalool $(6 \mathrm{mg})$

\subsection{Sanitation Felling and Tree Destruction}

All trees detected during the visual survey as showing A. glabripennis infestation symptoms were cut and destroyed (details below). Trees reporting unclear symptoms possibly confused with those potentially caused by others urban pests infesting the same host-trees (e.g., Cossus cossus (Lepidoptera: Cossidae), Zeuzera pyrina (Lepidoptera: Cossidae), Saperda carcharias (Coleoptera: Cerambycidae)) were cut and destroyed as well.

A. glabripennis adults leave the tree where they emerged only rarely-when they are strongly disturbed, for example, by tree felling. Moreover, adults were found to be active from the end of May to November. Therefore, infested trees found during the springsummer survey were marked but not cut immediately, to avoid adult dispersal during tree felling and movement of infested wood through the village. Tree felling, carried out by workers of the Regional Forest Service, was hence postponed every year to winter, between December and April, during insect hibernation as mature larvae [31]. Infested trees, from both public and private properties, were felled at ground level, leaving only stumps, and moved to a fenced and paved storage area falling within the infestation zone, but away from host plants. In winter, cut trees were then chipped in 2-cm long chips, and chips sold to a biomass power station outside the infestation area. Wood chips have been submitted to entomological analysis by the University of Padua in order to exclude the presence of 
live larvae. However, chips were moved to the biomass power station and burned by the end of winter to reduce the risk of dispersal outside the infestation area of woody material potentially infested with active A. glabripennis stages.

The first 4 years of eradication (2009-2012), tree cutting, and chipping only concerned infested plants and a few infested trees growing close to the attacked ones. Then, in order to make the eradication protocol more effective, the Regional Decree no. 33 of 10 September 2012 of the Veneto Region introduced the "Clear-cut" measure, which involved identification and cutting of all susceptible plants, even if apparently uninfested, occurring in the area within a $50 \mathrm{~m}$ radius from each infested plant. Since 2015 , considering the imminent approval of the Decision UE/2015/893 of the European Commission, the clearcut radius has been increased to $100 \mathrm{~m}$.

\subsection{Mitigation Plan}

In accordance with the owner's will, plants felled in private gardens were replaced for free with new trees belonging to non-host species. Young trees (3-4 years old) were chosen by the citizens among the species available for reforestation and urban design programs at the forest nursery of the Regional Forest Service, including Cercis siliquastrum, Clerodendrom trychotomum, Ginko biloba, Liquidambar styraciflua, Quercus robur, and Quercus pubescens.

\subsection{Communication}

Municipalities and other territorial authorities, such as schools, park administrators and citizens' associations, were immediately involved. Public meetings were organized to inform citizens, with the distribution of informative brochures and poster hanging, and releases were sent to local newspapers. Moreover, specific technical meetings were organized to inform and train local nurserymen, pruners, gardeners, and other professional stakeholders. Lastly, brief lessons were organized for students of primary and secondary schools of the territory, with projection of slides and photos concerning pest biology and symptoms. In this way, citizens were informed about the threat and how to recognize and report signs of the pest presence. A toll-free number was also activated to allow citizens to report suspect symptoms or A. glabripennis sightings. Finally, an internet site was activated providing information for citizens and a platform to upload reports.

\section{Results}

The eradication plan started in the summer of 2009 and ended in 2020 when, according to Commission regulation EU/2015/893, the species was declared eradicated from Cornuda and its surrounding municipalities [35], following four years of no new records of infested plants. Indeed, neither insects nor plants showing infestation symptoms (oviposition pits, emerging holes, or maturation feedings) have been found since 2016.

\subsection{Visual Tree Survey}

Since the beginning of monitoring in 2009, more than 36,000 trees were surveyed singly over twelve years (Table 2). Among the 16 surveyed genera, the most abundant were Acer (10,277 trees, 28\%), Ulmus (6227 trees, 17\%), Salix (5271 trees, 15\%), Carpinus (4837 trees, $13 \%$ ), and Betula (2067 trees, $6 \%$ ); other genera occurred in percentages lower than $5 \%$ (Table 2). 
Table 2. Number of monitored and infested trees, with relative percentages of infestation, divided by genera.

\begin{tabular}{cccc}
\hline Tree Genus & Monitored Plants (n) & Infested Plants (n) & Ratio (\%) \\
\hline Cercidiphyllum & 11 & 2 & 18.18 \\
Aesculus & 147 & 17 & 11.56 \\
Betula & 2067 & 210 & 10.16 \\
Ulmus & 6227 & 337 & 5.41 \\
Acer & 10,277 & 431 & 4.19 \\
Salix & 5271 & 149 & 2.83 \\
Prunus & 1361 & 9 & 0.66 \\
Populus & 1709 & 2 & 0.12 \\
Alnus & 59 & 0 & - \\
Carpinus & 4837 & 0 & - \\
Corylus & 1238 & 0 & - \\
Fagus & 486 & 0 & - \\
Fraxinus & 680 & 0 & - \\
Ostrya & 43 & 0 & - \\
Platanus & 908 & 0 & - \\
Tilia & 1040 & 0 & 3.18 \\
\hline Total & 36,361 & 1157 & - \\
\hline
\end{tabular}

During the survey carried out from 2009 to 2020, 1157 trees belonging to 8 genera were found to be infested ( $3 \%$ of the total amount of surveyed trees). The most at-tacked genera were Acer (431 trees infested), Ulmus (337 trees infested), Betula (210 trees infested), and Salix (149 trees infested) - even if, looking at the ratio between in-fested and monitored trees, the most susceptible genera were Cercidiphyllum (18.2\%), Aesculus (11.6\%) and Betula (10.2\%), followed by Ulmus (5.4\%), Acer (4.2\%), and Salix (2.8\%) (Table 2). Monitored but never found infested genera were Alnus, Carpinus, Cor-ylus, Fagus, Fraxinus, Ostrya, Platanus and Tilia (Table 2).

\subsection{Zone Delimitation}

In 2009, the year of the infestation discovery, the delimited zone had an area of 4105 ha which grew in the subsequent years, reaching the maximum size of 7594 ha in 2013 (Figure 2). In 2016, as a result of the application of the eradication protocol, both infestation and buffer zone began to decline, reaching the minimum value of 1843 ha in 2018 (Table 3).

Table 3. Extension of buffer zones, number of monitored and felled trees (divided in "infested" and susceptible trees), and clear-cut radius adopted for each year.

\begin{tabular}{|c|c|c|c|c|c|c|}
\hline Year & $\begin{array}{l}\text { Buffer Zone } \\
\text { (ha) }\end{array}$ & $\begin{array}{l}\text { Monitored } \\
\text { Plants } \\
\text { (n) }\end{array}$ & $\begin{array}{l}\text { Infested Plants } \\
\text { (n) }\end{array}$ & $\begin{array}{l}\text { Susceptible Plants } \\
\text { (Clear-Cut) } \\
\text { (n) }\end{array}$ & $\begin{array}{c}\text { Total Felled } \\
\text { Trees } \\
\text { (n) }\end{array}$ & $\begin{array}{l}\text { Clear-Cut Radius } \\
\text { (m) }\end{array}$ \\
\hline 2009 & 4105 & 12,816 & 576 & 54 & 630 & - \\
\hline 2010 & 5625 & 20,366 & 327 & 198 & 525 & - \\
\hline 2011 & 7214 & 24,292 & 163 & 82 & 245 & - \\
\hline 2012 & 7214 & 24,292 & 67 & 679 & 746 & 50 \\
\hline 2013 & 7594 & 25,223 & 15 & 83 & 98 & 50 \\
\hline 2014 & 7594 & 30,990 & 5 & 52 & 57 & 100 \\
\hline 2015 & 7594 & 36,361 & 4 & 56 & 60 & 100 \\
\hline 2016 & 4555 & 24,511 & 0 & 0 & 0 & 100 \\
\hline 2017 & 4555 & 24,511 & 0 & 0 & 0 & 100 \\
\hline 2018 & 1843 & 13,041 & 0 & 0 & 0 & 100 \\
\hline 2019 & 1843 & 13,041 & 0 & 0 & 0 & 100 \\
\hline Total (n) & & $36,361 *$ & 1157 & 1204 & 2361 & \\
\hline
\end{tabular}

${ }^{*}$ Healthy trees were monitored every year, so the total is not the sum of monitored trees for each year, but the total amount of monitored trees during the eradication period. Susceptible trees: healthy host-trees growing close to an infested tree. During the first three years, no clear-cuts were applied systematically; however, in the case of polychromic trees, or trees very close to infested ones, or trees damaged by felling-infested trees, felling was also carried out on plants that were not directly infested. 


\subsection{Pheromone Traps}

During the three year monitoring with traps (2011-2013), only two A. glabripennis females were caught in 2013. The two individuals were caught by one multi-funnel and one cross-vane trap, both baited with the ChemTica blend. In 2019, after three years without finding any attacked plants, traps were placed to provide further confirmation that eradication had taken place, and no individuals were caught.

\subsection{Sanitation Felling, Tree Destruction, and Mitigation Plan}

Beside the 1157 infested trees, another 1204 trees were felled because they were inside the "clear-cut area" (Table 3). Overall, a total of 2361 trees were cut in 12 years during the eradication plan applied in Cornuda, of which only 220 plants were from private gardens. The highest peak of felling occurred during the first year (2009), with 630 cut trees. Subsequently, the number was steadily decreasing with time, until no new plants were felled since 2016.

Two samples of wood chips, taken in 2010 and in 2011, have been submitted to an entomological analysis by the University of Padua. The analysis showed that the size of the wood pieces from the chipping operations is incompatible with the development and survival of $A$. glabripennis larvae in the wood; almost all of the material analysed was less than $2 \mathrm{~cm}$ in length, compared to $4-5 \mathrm{~cm}$ in length for mature larvae. In fact, several remains of crushed larvae were found during the analysis. Moreover, the few larger elements are subject to rapid deterioration due to tissue dehydration or fermentation, depending on the humidity conditions. In conclusion, the product tested was found to be biologically safe and free from risk of spreading $A$. glabripennis infestation.

Main costs incurred in carrying out eradication program were:

- $€ 380,000$ used by the Regional Plant Protection Organization for the annual tree survey (twice per year).

- $\quad € 520,000$ used by Regional Forest Services for felling and chipping trees.

- $€ 20,000$ used by the University of Padua for scientific support and research activities.

The program was initially financed by funds from the Veneto Region, which then accessed European funds for the management and eradication of invasive species.

As compensation for the felling of infested trees occurring in private properties, owners could choose a new tree to plant as a replacement. A total of 217 new trees (over 220 cut) were planted, including Cercis siliquastrum (65), Liquidambar styraciflua (41), Ginko biloba (35), Clerodendrom trychotomum (29), Quercus robur (27), and Quercus pubescens (20). There was no financial compensation.

\section{Discussion}

Eradication is the numerical reduction of a population in a specific geographic area to prevent its reproduction and, therefore, bring it to local extinction [37,38]. Conditions that support a higher probability of successful eradication include early detection of the pest (i.e., limited spatial distribution), ability to detect and identify the invader or the infested plants, availability of effective tools for pest monitoring and control, and public support $[39,40]$. Moreover, the target species should have all or most of the following characteristics: low rate of reproduction and dispersal, ease of detection at low population density, and limited host range [39].

Early detection of the pest plays a key role in a successful eradication program. The earlier the parasite is discovered from the time of actual arrival, the higher the chances of success, as the parasite will have less time to reproduce and spread. In fact, the probability of successful eradication declines with increases in the infested area [41,42]. In particular, Rejmánek and Pitcairn [42], analyzing data from 53 infestations of 18 pest species, showed that eradication success probability is about $50 \%$ between 0.1 and 1.0 hectares and about $25 \%$ between 100 and 1000 hectares of infested area. Moreover, as the area of eradication increases, the required efforts (i.e., costs) also increase and the operation may no longer be economically viable [40]. The Cornuda infestation initially measured about 4000 ha 
(infested and buffer zones) and expanded to a maximum extension of about 7600 ha. Although the infestation was discovered in 2009, it was verified, by dating the exit holes from the host trees, that the infestation started at least five years previously, in 2005 [31]. This delay in starting the eradication program caused an effort of eight years of active eradication (2009-2016) and another four years (2017-2020) of surveying in order to eradicate A. glabripennis from the territory. The monitoring protocol involved more than 36,000 trees checked one-by-one twice a year for 11 years; 2361 of these trees were felled because they were found to be infested or simply because they were within the clear-cut radius. Another example of successful A. glabripennis eradication is at Paddock Wood (Kent, UK), although in this case the infestation was much smaller (with an infested zone of only 11.4 ha). After just one year (and another seven years of surveying) the pest was eradicated and about 2200 trees were felled, of which 66 were infested [43,44]. In contrast, a large infestation was detected in Worcester (MA, USA) in 2008 [5], and is still active [45]. Until 2015, the extension of the infestation was larger than 20,000 ha with more than 5 million monitored trees, of which approximately 34,000 were removed (both infested, and those deemed to be high-risk) [46]. Such a wide spread makes a successful eradication challenging [5].

Besides early detection, a successful eradication is based on the possibility of easily identifying the pest or its infestation symptoms and the disposal of effective tools for its detection. Visual inspections have proved to be effective against $A$. glabripennis, but they lose effectiveness for recently infested trees [43], or in the case of large trees or trunks covered by ivy (Faccoli, pers. observ.). Pheromone traps are often used alongside the work of phytosanitary inspectors, both to find pests and for their eradication by masstrapping and lure-and-kill techniques [47-50]. Unfortunately, no long-range pheromone has been reported for $A$. glabripennis, although both male-produced short-range and femaleproduced contact recognition pheromones have been identified [3,4,51,52]. Several studies have tested the effectiveness of these pheromones combined with some host-volatiles (e.g., Z-3-hexen-1-ol and Linalool) in trapping protocols, showing some positive outcomes, but with few catches despite the dozens of traps used [53-55]. During the eradication program carried out in Cornuda, only two A. glabripennis females were caught by traps in 2013 and no A. glabripennis individuals were caught by traps used at Paddock Wood [43]. Despite the use of $A$. glabripennis pheromones remaining indicated for pest interception in areas where it is not yet been detected [56], our results corroborate the hypothesis that the attraction of pheromones is not strong enough to be used for active eradication actions by mass-trapping, and probably not even for reliable monitoring. The low effectiveness of pheromone-based trapping techniques is probably due to the fact that they mainly attract virgin females and, at close range, females also used other visual and chemical stimuli which require further study [57].

Despite A. glabripennis having many of ecological and biological characteristics indicated by Brockerhoff et al. [39] as facilitating their eradication, an effective A. glabripennis eradication is never easy because of its extreme polyphagy and the generic symptoms it causes to host plants. First of all, A. glabripennis has a low fecundity rate [3]. In China, under natural conditions, 25-40 viable eggs were estimated per female [4], whereas in the USA that fecundity was estimated to vary between 30-178 eggs per female [58,59]. Additionally, their limited active dispersal capacity is an important factor. The potential dispersal of A. glabripennis adults was estimated at about $2000 \mathrm{~m}$, with a realistic annual spread of about $300 \mathrm{~m}$ from the closest infested tree [56,60,61]. Moreover, the tendency to reinfest the same tree for several years was usually observed [3,4]. Lastly, according to climatic conditions A. glabripennis takes 1-3 years or even more to fully complete its life cycle $[3,4]$. All these characteristics (i.e., fecundity, active fly, and life cycle duration) strictly depend on temperature [62]. In Cornuda, annual temperatures range between -2 and $29{ }^{\circ} \mathrm{C}$, with a mean temperature of $23^{\circ} \mathrm{C}$ during warmer months [63]. In Paddock Wood annual temperatures vary between 2 and $23^{\circ} \mathrm{C}$, with a mean temperature of $17^{\circ} \mathrm{C}$ during warmer months [64]. The first effects of the different climatic conditions at the two sites can be observed on the life cycle. In northern Italy A. glabripennis was considered 
univoltine [61], whereas for the UK a 2-3 year life cycle was estimated [64]. Moreover, research carried out on the effects of temperature on A. glabripennis fecundity estimated that the optimum temperature for maximum fecundity is about $25^{\circ} \mathrm{C}$ [59]. Another study showed that the adult's flight capacity increases with temperatures from 15 to $30^{\circ} \mathrm{C}$, and that no flight occurs under $15^{\circ} \mathrm{C}$ [65]. In conclusion, lower temperatures of Paddock Wood caused a lower A. glabripennis adult fecundity, lower flight propensity (i.e., lower dispersion of the infestation), and lengthening of development time-doubling or even tripling it compared to the Cornuda infestation. All these factors probably contributed to keeping the pest infestation low in the UK, despite the eradication beginning about ten years after the estimated arrival of the pest [66], whereas in Italy only five years had elapsed.

One of the major problems in dealing with A. glabripennis eradication concerns its extreme polyphagy on woody broadleaves. An extensive investigation conducted in the Yinchuan region (China) found damage on trees belonging to 14 genera of broadleaves, although complete development has not been confirmed on all species listed as hosts [4]. However, host suitability differs in different continents: Populus and Salix are more suitable than Ulmus in China [4]; Acer and Ulmus are generally more suitable than Fraxinus in the USA [15,67]; in Europe the most suitable genera are, in decreasing order, Acer, Betula, Salix, Aesculus and Populus [18]. In the Cornuda infestation the most infested genera (by percentage) were Betula, Ulmus, Acer, and Salix (excluding Cercidiphyllum and Aesculus because of the small number of trees present) - similar to infestations in other Italian regions (Lombardy, Marche, and Piedmont) [35] and to the infestation at Paddock Wood, where the most-attacked genera were Acer, Salix, and Betula [43,44]. Interestingly, in both the Cornuda and Paddock Wood infestations, the number of infested poplars was very low; this is particularly evident in Italy, were only 2 out of 1709 poplars $(0.1 \%)$ were found to be infested. In contrast, poplars are among the most suitable hosts for A. glabripennis in China, even if not all Populus species are equally susceptible to A. glabripennis [68]. Acer, instead, is confirmed as one of the main hosts for A. glabripennis. Such a large polyphagy has important consequences in the management of A. glabripennis infestations. A higher number of potential hosts means, on one hand, higher chances for the pest to reproduce and proliferate and, on the other hand, a higher number of trees to be surveyed and, if infested, to be felled and replaced. Moreover, A. glabripennis infests healthy and vigorous trees $[3,4]$, which makes prevention more difficult, as keeping plants healthy and in good physiological condition does not prevent infestations.

The eradication of A. glabripennis from the municipality of Cornuda shows the importance of taking prompt, coordinated, and effective actions to contain the spread of the pest and to proceed with its systematic elimination from the infested area. Despite the considerably large size of the Italian infestation, the benefits obtained from the eradication of the pest have far exceeded the costs incurred for its implementation [69]. Of course, different scenarios may occur. For example, the A. glabripennis infestation occurring in Worcester (Massachusetts) seems to be too widespread now and the eradication, although it remains the goal, is of uncertain outcome and is taking enormous effort [46].

Of all the actions undertaken, those that proved the most effective were visual survey of susceptible trees (in order to find signs of infestation) and the felling and destruction of all the infested trees and nearby ones (in order to prevent the diffusion of the pest). Additionally, the destruction of felled trees by chipping is a very useful practice in order to kill all the larvae present inside the wood, as demonstrated by the wood chip analyses conducted by the University of Padua and already reported in other works [57,70]. On the other hand, the use of pheromone traps proved useless, as was also the case during the eradication in Paddock Wood [43]. Finally, the involvement and active participation of citizens and stakeholders is also of paramount importance [39,71]. If not properly motivated, 'unpopular' actions such as felling private trees and killing insects may lead to protests and non-cooperation by the population, jeopardizing the outcome of the whole operation. In this respect, the first report of the presence of A. glabripennis in Cornuda was 
made by a private citizen, demonstrating the importance of citizens' cooperation in the interception of alien species.

Author Contributions: Conceptualization, M.M. and M.F.; methodology, M.M. and M.F.; formal analysis, M.M.; writing—original draft preparation, M.M.; writing—review and editing, M.F.; funding acquisition, M.F. All authors have read and agreed to the published version of the manuscript.

Funding: This research was partially financed by the Regional Plant Protection Organization of the Veneto Region and by the DOR projects of the University of Padua.

Institutional Review Board Statement: Not applicable.

Data Availability Statement: Not applicable.

Acknowledgments: We thank the phytosanitary office of the Regional Plant Protection Organization (RPPO) for data provided and their help in fieldwork; the staff of U.O. Forestale of Treviso for data provided and their help in fieldwork; and Oleg Kulinich (Department of Forest Quarantine, of the All-Russian Center of Plant Quarantine of Moscow) for providing Russian lures.

Conflicts of Interest: The authors declare no conflict of interest. The funders had no role in the design of the study; in the collection, analyses, or interpretation of data; in the writing of the manuscript; or in the decision to publish the results.

\section{References}

1. Lingafelter, S.W.; Hoebeke, E.R. Revision of the Genus Anoplophora (Coleoptera: Cerambycidae); Entomological Society of Washington: Washington, DC, USA, 2002.

2. Wang, Z.G. Study on the Occurrence Dynamics of Anoplophora glabripennis (Coleoptera: Cerambycidae) and its Control Measures. Ph.D. Thesis, Northeast Forestry University, Harbin, China, 2004.

3. Haack, R.A.; Hérard, F.; Sun, J.; Turgeon, J.J. Managing invasive populations of Asian Longhorned Beetle and Citrus Longhorned Beetle: A worldwide perspective. Annu. Rev. Entomol. 2010, 55, 521-546. [CrossRef]

4. Hu, J.; Angeli, S.; Schuetz, S.; Luo, Y.; Hajek, A.E. Ecology and management of exotic and endemic Asian longhorned beetle Anoplophora glabripennis. Agric. For. Entomol. 2009, 11, 359-375. [CrossRef]

5. Dodds, K.J.; Orwig, D.A. An invasive urban forest pest invades natural environments-Asian longhorned beetle in northeastern US hardwood forests. Can. J. For. Res. 2011, 41, 1729-1742. [CrossRef]

6. He, P.; Huang, J. Adult behavior of Anoplophora glabripennis. Acta Entomol. Sin. 1993, 36, 51-55.

7. Gao, R.; Xixiang, Q.; Dejun, C.; Weipei, C. A Study on the damage of poplar caused by Anoplophora glabripennis. For. Res. 1993, 6, 189-193.

8. Haugen, D.A. Update on Asian longhorned beetle infestations in the US. Newsl. Mich. Entomol. Soc. 2000, 45, 2-3.

9. Nowak, D.J.; Pasek, J.E.; Sequeira, R.A.; Crane, D.E.; Mastro, V.C. Potential effect of Anoplophora glabripennis (Coleoptera: Cerambycidae) on urban trees in the United States. J. Econ. Entomol. 2001, 94, 116-122. [CrossRef] [PubMed]

10. Cavey, J.F.; Hoebeke, E.R.; Passoa, S.; Lingafelter, S.W. A new exotic threat to North American hardwood forests: An Asian longhorned beetle, Anoplophora glabripennis (Motschulsky) (Coleoptera: Cerambycidae). I. Larval description and diagnosis. Proc. Entomol. Soc. Washingt. 1998, 100, 373-381.

11. Haack, R.A.; Cavey, J.F.; Hoebeke, E.R.; Law, K.R. Anoplophora glabripennis: A new tree-infesting exotic cerambycid invades New York. Newsl. Mich. Entomol. Soc. 1996, 41,1-3.

12. Shatz, A.J.; Rogan, J.; Sangermano, F.; Ogneva-Himmelberger, Y.; Chen, H. Characterizing the potential distribution of the invasive Asian longhorned beetle (Anoplophora glabripennis) in Worcester County, Massachusetts. Appl. Geogr. 2013, 45, $259-268$. [CrossRef]

13. Poland, T. Chicago joins New York in battle with the Asian longhorned beetle. Newsl. Mich. Entomol. 1998, 43, 15-17.

14. Haack, R.A. Exotics, exotics, exotics: Recently detected bark-and wood-boring insects in the US. Newsl. Mich. Entomol. Soc. 2003, $48,16-17$.

15. Coyle, D.R.; Trotter, R.T.; Bean, M.S.; Pfister, S.E. First recorded Asian Longhorned Beetle (Coleoptera: Cerambycidae) infestation in the Southern United States. J. Integr. Pest Manag. 2021, 12, 10-11. [CrossRef]

16. Pedlar, J.H.; McKenney, D.W.; Yemshanov, D.; Hope, E.S. Potential economic impacts of the Asian Longhorned Beetle (Coleoptera: Cerambycidae) in Eastern Canada. J. Econ. Entomol. 2020, 113, 839-850. [CrossRef] [PubMed]

17. Tomiczek, C.; Krehan, H.; Menschhorn, P. Dangerous Asiatic longicorn beetle found in Austria: New danger for our trees. Allg. Forst Z. Waldwirtsch. Umweltvorsorge 2002, 57, 52-54.

18. Hérard, F.; Ciampitti, M.; Maspero, M.; Krehan, H.; Benker, U.; Boegel, C.; Schrage, R.; Bouhot-Delduc, L.; Bialooki, P. Anoplophora species in Europe: Infestations and management processes. EPPO Bull. 2006, 36, 470-474. [CrossRef]

19. Benker, U.; Bogel, C.; Blaschke, M. Tree fellings due to black longicorn beetle: The asiatic longicorn beetle has been found in the district of Passau [Bavaria, Germany]. Allg. Forst Z. Waldwirtsch. Umweltvorsorge 2004, 59, 1112. 
20. EPPO. First record of Anoplophora glabripennis in Italy. EPPO Report. Serv. 2007, 9, 2.

21. EPPO. First record of Anoplophora glabripennis in the Netherlands. EPPO Report. Serv. 2010, 11, 2.

22. EPPO. First report of Anoplophora glabripennis in Switzerland. EPPO Report. Serv. 2011, 9, 3-4.

23. EPPO. First outbreak of Anoplophora glabripennis in the United Kingdom. EPPO Report. Serv. 2012, 4, 2.

24. EPPO. Anoplophora glabripennis found in Corse (FR). EPPO Report. Serv. 2013, 7, 2-3.

25. EPPO. First report of Anoplophora glabripennis in Finland. EPPO Report. Serv. 2015, 10, 4-5.

26. EPPO. First report of Anoplophora glabripennis in Montenegro. EPPO Report. Serv. 2017, 1, 3-4.

27. EPPO. EPPO Global Database. Available online: https://gd.eppo.int/taxon/ANOLGL/distribution (accessed on 2 September 2021).

28. EPPO. Anoplophora glabripennis detected in the Veneto region, Italy. EPPO Report. Serv. 2009, 8, 4.

29. EPPO. Anoplophora glabripennis found in Piemonte, Italy. EPPO Report. Serv. 2018, 10, 6-7.

30. EPPO. Anoplophora glabripennis found for the first time in Marche region, Italy. EPPO Report. Serv. 2013, 9, 4.

31. Faccoli, M.; Favaro, R.; Smith, M.T.; Wu, J. Life history of the Asian longhorn beetle Anoplophora glabripennis (Coleoptera: Cerambycidae) in southern Europe. Agric. For. Entomol. 2015, 17, 188-196. [CrossRef]

32. Faccoli, M.; Favaro, R. Host preference and host colonization of the Asian long-horned beetle, Anoplophora glabripennis (Coleoptera: Cerambycidae), in Southern Europe. Bull. Entomol. Res. 2016, 106, 359-367. [CrossRef]

33. Faccoli, M.; Vettorazzo, M.; Zampini, M.; Zanini, G.; Coppe, M.; Battisti, A. An outbreak of Anoplophora glabripennis (Coleoptera: Cerambycidae) in NE Italy: First results of pest management and eradication attempt. Proc. IUFRO Work. Party 2011, 7, 3-5.

34. EPPO. PM 9/15 (1) Anoplophora glabripennis: Procedures for official control. EPPO Bull. 2013, 43, 510-517. [CrossRef]

35. EPPO. Update on the situation of Anoplophora glabripennis in Italy. EPPO Report. Serv. 2020, 10, 12-13.

36. Williams, D.W.; Lee, H.-P.; Kim, I.-K. Distribution and abundance of Anoplophora glabripennis (Coleoptera: Cerambycidae) in natural acer stands in South Korea. Environ. Entomol. 2004, 33, 540-545. [CrossRef]

37. Myers, J.H.; Savoie, A.; van Randen, E. Eradication and pest management. Annu. Rev. Entomol. 1998, 43, 471-491. [CrossRef] [PubMed]

38. Liebhold, A.M.; Tobin, P.C. Population ecology of insect invasions and their management. Annu. Rev. Entomol. 2008, 53, 387-408. [CrossRef] [PubMed]

39. Brockerhoff, E.G.; Liebhold, A.M.; Richardson, B.; Suckling, D.M. Eradication of invasive forest insects: Concepts, methods, costs and benefits. N. Z. J. For. Sci. 2010, 40, 117-135.

40. Tobin, P.C.; Kean, J.M.; Suckling, D.M.; McCullough, D.G.; Herms, D.A.; Stringer, L.D. Determinants of successful arthropod eradication programs. Biol. Invasions 2014, 16, 401-414. [CrossRef]

41. Pluess, T.; Jarošík, V.; Pyšek, P.; Cannon, R.; Pergl, J.; Breukers, A.; Bacher, S. Which factors affect the success or failure of eradication campaigns against alien species? PLoS ONE 2012, 7, e48157. [CrossRef] [PubMed]

42. Rejmánek, M.; Pitcairn, M. When is eradication of exotic pest plants a realistic goal. In Turning the Tide: The Eradication of Invasive Species; Veitch, C., Clout, M., Eds.; IUCN: Gland, Switzerland, 2002; pp. 249-253.

43. Eyre, D.; Barbrook, J. The eradication of Asian longhorned beetle at Paddock Wood, UK. CABI Agric. Biosci. 2021, 2, 1-17. [CrossRef]

44. Straw, N.A.; Fielding, N.J.; Tilbury, C.; Williams, D.T.; Inward, D. Host plant selection and resource utilisation by Asian longhorn beetle Anoplophora glabripennis (Coleoptera: Cerambycidae) in southern England. Forestry 2015, 88, 84-95. [CrossRef]

45. Santos, R.; Bond, S. USDA Announces 2021 Plans for Asian Longhorned Beetle Eradication Efforts in Massachusetts, New York, Ohio and South Carolina. Available online: https://www.aphis.usda.gov/aphis/newsroom/news/sa_by_date/sa-2021/alberadication-efforts (accessed on 2 September 2021).

46. Trotter, R.T.; Hull-Sanders, H.M. Quantifying dispersal of the Asian longhorned beetle (Anoplophora glabripennis, Coleoptera) with incomplete data and behavioral knowledge. Biol. Invasions 2015, 17, 3359-3369. [CrossRef]

47. El-Sayed, A.M.; Suckling, D.M.; Wearing, C.H.; Byers, J.A. Potential of mass trapping for long-term pest management and eradication of invasive species. J. Econ. Entomol. 2006, 99, 1550-1564. [CrossRef] [PubMed]

48. Suckling, D.M.; Stringer, L.D.; Stephens, A.E.; Woods, B.; Williams, D.G.; Baker, G.; El-Sayed, A.M. From integrated pest management to integrated pest eradication: Technologies and future needs. Pest Manag. Sci. 2014, 70, 179-189. [CrossRef]

49. El-Sayed, A.M.; Suckling, D.M.; Byers, J.A.; Jang, E.B.; Wearing, C.H. Potential of “Lure and Kill” in long-term pest management and eradication of invasive species. J. Econ. Entomol. 2009, 102, 815-835. [CrossRef] [PubMed]

50. Sanchez-Husillos, E.; Etxebeste, I.; Pajares, J. Effectiveness of mass trapping in the reduction of Monochamus galloprovincialis Olivier (Col.: Cerambycidae) populations. J. Appl. Entomol. 2015, 139, 747-758. [CrossRef]

51. Zhang, A.; Oliver, J.E.; Chauhan, K.; Zhao, B.; Xia, L.; Xu, Z. Evidence for contact sex recognition pheromone of the Asian longhorned beetle, Anoplophora glabripennis (Coleoptera: Cerambycidae). Naturwissenschaften 2003, 90, 410-413. [CrossRef]

52. Zhang, A.; Oliver, J.E.; Aldrich, J.R.; Wang, B.; Mastro, V.C. Stimulatory beetle volatiles for the Asian Longhorned Beetle, Anoplophora glabripennis (Motschulsky). Z. Naturforsch. C 2002, 57, 553-558. [CrossRef]

53. Nehme, M.E.; Keena, M.A.; Zhang, A.; Baker, T.C.; Xu, Z.; Hoover, K. Evaluating the use of male-produced pheromone components and plant volatiles in two trap designs to monitor Anoplophora glabripennis. Environ. Entomol. 2010, 39, 169-176. [CrossRef] 
54. Nehme, M.E.; Keena, M.A.; Zhang, A.; Baker, T.C.; Hoover, K. Attraction of Anoplophora glabripennis to male-produced pheromone and plant volatiles. Environ. Entomol. 2009, 38, 1745-1755. [CrossRef]

55. Nehme, M.E.; Trotter, R.T.; Keena, M.A.; McFarland, C.; Coop, J.; Hull-Sanders, H.M.; Meng, P.; De Moraes, C.M.; Mescher, M.C.; Hoover, K. Development and evaluation of a trapping system for Anoplophora glabripennis (Coleoptera: Cerambycidae) in the United States. Environ. Entomol. 2014, 43, 1034-1044. [CrossRef]

56. Hoppe, B.; Schrader, G.; Kinkar, M.; Vos, S. Pest survey card on Anoplophora glabripennis. EFSA Support. Publ. 2019, 16, 1750E.

57. Branco, S.; Faccoli, M.; Brockerhoff, E.G.; Roux, G.; Jactel, H.; Desneux, N.; Gachet, E.; Mouttet, R.; Streito, J.-C.; Branco, M. Preventing invasions of Asian longhorn beetle and citrus longhorn beetle: Are we on the right track? J. Pest Sci. $2021,1-26$. [CrossRef]

58. Keena, M.A. Anoplophora glabripennis (Coleoptera: Cerambycidae) fecundity and longevity under laboratory conditions: Comparison of populations from New York and Illinois on Acer saccharum. Environ. Entomol. 2002, 31, 490-498. [CrossRef]

59. Keena, M.A. Effects of temperature on Anoplophora glabripennis (Coleoptera: Cerambycidae) adult survival, reproduction, and egg hatch. Environ. Entomol. 2006, 35, 912-921. [CrossRef]

60. Smith, M.T.; Tobin, P.C.; Bancroft, J.; Li, G.; Gao, R. Dispersal and spatiotemporal dynamics of Asian Longhorned Beetle (Coleoptera: Cerambycidae) in China. Environ. Entomol. 2004, 33, 435-442. [CrossRef]

61. Favaro, R.; Wichmann, L.; Ravn, H.P.; Faccoli, M. Spatial spread and infestation risk assessment in the Asian longhorned beetle, Anoplophora glabripennis. Entomol. Exp. Appl. 2015, 155, 95-101. [CrossRef]

62. Kappel, A.P.; Trotter, R.T.; Keena, M.A.; Rogan, J.; Williams, C.A. Mapping of the Asian longhorned beetle's time to maturity and risk to invasion at contiguous United States extent. Biol. Invasions 2017, 19, 1999-2013. [CrossRef]

63. ARPAV (Agenzia Regionale per la Prevenzione e Protezione Ambientale Veneto). Dati Meteorologici Ultimi Anni. Available online: https:/ / www.arpa.veneto.it/bollettini/storico/ (accessed on 2 September 2021).

64. Straw, N.A.; Tilbury, C.; Fielding, N.J.; Williams, D.T.; Cull, T. Timing and duration of the life cycle of Asian longhorn beetle Anoplophora glabripennis (Coleoptera: Cerambycidae) in southern England. Agric. For. Entomol. 2015, 17, 400-411. [CrossRef]

65. Keena, M.A. Factors that influence flight propensity in Anoplophora glabripennis (Coleoptera: Cerambycidae). Environ. Entomol. 2018, 47, 1233-1241. [CrossRef]

66. Straw, N.A.; Fielding, N.J.; Tilbury, C.; Williams, D.T.; Cull, T. History and development of an isolated outbreak of Asian longhorn beetle Anoplophora glabripennis (Coleoptera: Cerambycidae) in southern England. Agric. For. Entomol. 2016, 18, 280-293. [CrossRef]

67. Haack, R.; Bauer, L.; Gao, R.-T.; McCarthy, J.; Miller, D.; Petrice, T.; Poland, T. Anoplophora Glabripennis within-tree distribution, seasonal development, and host suitability in China and Chicago. Gt. Lakes Entomol. 2006, 39, 169-183.

68. Yin, W.L.; Lu, W. Review of Tree Selection and Afforestation for Control of Asian Longhorned Beetle in North China; Forest Health \& Biosecurity Working Paper FBS/7E; Food and Agriculture Organization of the United Nations: Rome, Italy, 2005.

69. Faccoli, M.; Gatto, P. Analysis of costs and benefits of Asian longhorned beetle eradication in Italy. Forestry 2016, 89, 301-309. [CrossRef]

70. Wang, B.; Mastro, V.C.; McLane, W.H. Impacts of chipping on surrogates for the longhorned beetle Anoplophora glabripennis (Coleoptera: Cerambycidae) in logs. J. Econ. Entomol. 2000, 93, 1832-1836. [CrossRef] [PubMed]

71. Porth, E.F.; Dandy, N.; Marzano, M. "My garden is the one with no trees": Residential lived experiences of the 2012 Asian Longhorn Beetle eradication programme in Kent, England. Hum. Ecol. 2015, 43, 669-679. [CrossRef] 